\begin{tabular}{|c|c|c|}
\hline \multirow{3}{*}{$\begin{array}{l}\text { EREM 73/3 } \\
\text { Journal of Environmental Research, } \\
\text { Engineering and Management } \\
\text { Vol. } 74 \text { / No. } 1 \text { / } 2017 \\
\text { pp. 7-20 } \\
\text { DOI 10.5755/j01.erem.73.4.19941 } \\
\text { @ Kaunas University of Technology }\end{array}$} & \multicolumn{2}{|c|}{$\begin{array}{l}\text { Food Waste Generation and Prevention Measures } \\
\text { in the Retail Sector: A Comparative Study }\end{array}$} \\
\hline & Received 2018/01 & Accepted after revision 2018/02 \\
\hline & \multicolumn{2}{|c|}{ Crossef http://dx.doi.org/10.5755/j01.erem.73.4.19941 } \\
\hline
\end{tabular}

\title{
Food Waste Generation and Prevention Measures in the Retail Sector: A Comparative Study
}

\section{Daina Kliaugaitè, Jolita Kruopienè}

Institute of Environmental Engineering, Kaunas University of Technology, Lithuanian

Corresponding author: daina.kliaugaite@gmail.com

Institute of Environmental Engineering, Kaunas University of Technology, Gedinimo g. 50, Kaunas 44239, Lithuanian

Food waste in the supply chain is a big issue because it causes an unnecessary environmental impact, costs to the sector and consumers, as well as costs for waste treatment. Besides, it is a missed opportunity to feed people suffering from hunger. Calculations show that approximately $30 \%$ of all world food produced for human consumption is lost or wasted at some stage of the food supply chain, with the retail sector being responsible for approximately $5 \%$ of losses in developed countries. Several studies on food waste and losses have been performed in the international and national perspectives. These studies mostly give an overall food chain perspective and do not provide detailed information about food waste in specific stages or locations. The retail sector is one of the actors of the supply chain where there is still a gap in data and information regarding the state of the problem of food waste, especially in the Central and Eastern European region. The number of currently conducted studies regarding amounts of retail food waste, its types, causes and methods of waste minimization is limited or hindered by poor data resolution, because most retailers do not publicize the information about the quantities of wastes and their treatment. Therefore, a better understanding of food wastage within retail stores is necessary in order to assess the actual scale of the problem and to determine efficient waste prevention measures.

This work aims at food losses assessment in the Lithuanian retail sector, as well as discussion and comparison of the root causes of food waste generation with the neighbouring countries in North Europe, in order to facilitate food waste prevention measures. Semi-structured questionnaire survey was chosen as a data collection method as it allowed for collection of comprehensive and comparable information on food losses in a relatively short time. The data were collected at 21 retail stores, which belong to 3 biggest retail chains in Lithuania. For the comparative study, available literature on food waste assessment and prevention practices in Nordic countries was analyzed. 
The data from interviews reveal quantities of food waste generated in the Lithuanian retail sector, the composition of the food waste, as well as the sector's attitude to the problem and willingness to contribute to solving it. Differences in food waste in different retail chains and variations depending on the season of the year were evaluated as well. A comparative study with the neighbouring countries highlighted similarities and differences in waste generation, pointed to the potential prevention measures as well as learning opportunities for food waste minimization.

Keywords: food waste, retail stores, waste prevention, seasonal variation.

\section{Introduction}

Food waste appears at various stages of the food supply chain via the processes of production, processing, distribution, retailing, consumption and disposal. This causes significant problems in three major areas: environmental, economic and social (Eriksson, Strid, \& Hansson, 2014). Environmentally, food waste represents a substantial loss of natural resources such as land, water and energy, and causes unnecessary greenhouse gas emissions, which in turn leads to diminished natural ecosystems (Lipinski et al., 2013; Walter \& Marina, 2015). At the European level alone, at least 170 million tonnes of CO2eq. (approximately $3 \%$ of total EU-27 emissions in 2008) are emitted annually along all steps of the life cycle of disposed food (BIO Intelligence Service, 2010). Economically, food waste costs to the sector and consumers, as well as causes a high waste treatment cost. In addition, it represents wasted investments that can reduce producers' incomes and increase consumers' expenses (Lipinski et al., 2013). US businesses and consumers lose about EUR 145 billion (USD 198 billion) per year because of discarded food (Venkat, 2011). In the UK, thrown away food which is suitable for human consumption costs EUR 12.4 billion ( $£ 10.2$ billion) per year (Ventour, 2008). The costs related to the value of the food that has been wasted within wholesale and retail were estimated to be 10 billion of euros per year for the whole EU, the cost per tonne of edible food waste being EUR 2,768 (Stenmarck et al., 2016).

From a social perspective, food waste is a lost opportunity to feed the growing world population and the 870 million people globally or $12 \%$ of the world population who are in need of food (Gustavsson, Cederberg, \& Sonesson, 2011). The global population is forecasted to grow from the current 7 billion to 9 billion by 2050 , creating the need for an increased food production of
$70 \%$. In the EU, the rising price of food resources and the volatility in the market have put pressure on the access to high quality food for the lower social economic groups within Europe (FAO, 2009).

The calculations done by the Food and Agricultural Organization of the United Nations (FAO) show that about one-third of food produced for human consumption is wasted globally (2009 data), which amounts to about 1.3 billion tonnes per year (Gustavsson et al., 2011). Breaking it down into different food types, globally, roughly $30 \%$ of cereals, $40-50 \%$ of root crops, fruits and vegetables, $20 \%$ of oilseeds, meat and dairy, and $30 \%$ of fish are discarded annually (Gustavsson et al., 2011).

Regionally, about $56 \%$ of total food loss and waste occurs in the developed world - North America, Oceania, Europe, and the industrialized Asian nations of China, Japan, and South Korea - whereas the developing world accounts for $44 \%$ of the loss (Lipinski et al., 2013). The project FUSIONS estimated that in the EU alone nearly 90 million tonnes of food or $173 \mathrm{~kg}$ per capita are wasted every year. This is divided between the various stages in the food chain as follows: $11 \%$ from primary production, $19 \%$ from processing, $5 \%$ from wholesale and retail, 53\% from households, and $14 \%$ from food services outside the home. Much of this is food still suitable for human consumption (Stenmarck et al., 2016)directly linked with environmental (e.g. energy, climate change, water, availability of resources. For these reasons, the food sector and food waste reduction are among the key areas highlighted in 2011 communication "The Roadmap to a Resource Efficient Europe", where the EC sets out a 50\% food waste reduction target for 2020 (European Commision, 2011). The similar target on avoidable food is stated in the resolution of the European Parliament. It asks to create specific food waste 
prevention targets for the Member States and halve food waste by 2025 (European Parliament Resolution (2011/2175(INI)), 2012). In order to solve the problem and reach the targets, the initiatives to reduce waste in different regions and by different actors in the food supply chain need to be taken.

The research work on food waste and prevention varies with respect to different regions. Schneider (2013) indicates that a large amount of information in English about food waste and prevention initiatives is available in regions such as North America, Western Europe, to a lesser extent in Northern Europe and Australia, while studies from Southern and Eastern European countries are rare. As reported by Schneider (2013), researchers of Eastern European countries focus mostly on topics such as the collection or proper disposal of waste (Schneider, 2013). The most significant studies there have been undertaken on behalf of the UK body, the Waste and Resources Action (Walter \& Marina, 2015).

It is important to mention international level studies that cover knowledge of global food waste amounts, general causes and prevention in industrialized and non-industrialized countries (Lipinski et al., 2013) situation analyses on food waste across EU (BIO Intelligence Service, 2010; Stenmarck et al., 2016)directly linked with environmental (e.g. energy, climate change, water, availability of resources the state of the problem of food waste in the Baltic region (Walter \& Marina, 2015).

There are some recently published studies focusing on different food waste issues along the supply chain: food waste generation and prevention in food processing industry (Møller, Vold, Schakenda, \& Hanssen, 2012) and households (Edjabou, Petersen, Scheutz, \& Astrup, 2016; Hanssen, Syversen, \& Stø, 2016; Katajajuuri, Silvennoinen, Hartikainen, Heikkilä, \& Reinikainen, 2014; Koivupuro et al., 2012; Nahman, de Lange, Oelofse, \& Godfrey, 2012; T. E. Quested, Marsh, Stunell, \& Parry, 2013; T. Quested \& Parry, 2011). Others deal with the food waste topic along the whole supply chain (Beretta, Stoessel, Baier, \& Hellweg, 2013; Katajajuuri et al., 2014; Parfitt, Barthel, \& Macnaughton, 2010; Terry, Mena, Williams, Jenney, \& Whitehead, 2011), estimating the environmental impact of food waste (Venkat, 2011) or discussing packaging issues (Wikström, Williams, Verghese, \& Clune, 2014). Several studies have been done to cover food waste generation, causes and prevention with respect to retail (Eriksson, Strid, \& Hansson, 2012; Lebersorger \& Schneider, 2014; Stenmarck, Jörgen Hanssen, Silvennoinen, \& Katajajuuri, 2011). Evaluations show the retail sector being responsible for approximately $5 \%$ of losses in the supply chain in developed countries (Gustavsson et al., 2011; Stenmarck et al., 2016), for example, with the estimates of $3.8 \%$ in the Swedish supply chain (Eriksson et al., 2014). Although the percentage of waste in supermarkets is lower than in other stages of the food supply chain, the amounts are still high, with 39,000 wasted tonnes per annum in Sweden (Eriksson et al., 2014) and 4.6 million tonnes per annum in the whole European Union (Stenmarck et al., 2016). Worldwide, retailers throw away 1.6 million tonnes of food per year (Fox \& Fimeche, 2013). Results of the FAO's study reveal that in developing countries food is to a significant extent wasted at the post harvest and processing levels, while in industrialized countries food is lost mostly at the consumer and retail level (Gustavsson et al., 2011). It is not only amounts of waste that make the retail sector important, but also the link between producers and consumers. Thus, food waste in industrialized countries can be reduced by raising awareness among food industries, retailers and consumers (Eriksson et al., 2012).

Despite the studies that have been done, most of them reveal the major data gaps in available information about the state of the problem of food waste generated at the national levels at each stage of the supply chain. Therefore, the retail sector is one of important actors in the food supply chain, where food waste studies at present are rather a new area, especially in some regions as Eastern European countries. Moreover, the food waste findings at present are hindered by poor data resolution; most shopping centers do not publicize the information about the quantities of wastes and their treatments. Better understanding of the wastage within retail stores is necessary for efficient waste prevention measures.

This work aimed at food waste assessment in the Lithuanian retail sector as well as discussion and 
comparison of the root causes of retail food waste generation in Lithuania and its neighbouring countries, in order to find possible ways of preventing them.

\section{Materials and methods}

\section{Definitinion of food loss and food waste}

The interpretation of the terms "food loss" and "food waste" depends on each particular research group and the boundaries of group's work (Wikström et al., 2014). Food losses and food waste can be defined as any product initially intended for human consumption, excluding products that are not for use as food that is thrown out or destroyed at every stage in the food chain from farm to consumer (Gustavsson et al., 2011).

According to the FAO, food losses occur at the start of the food chain (primary production, post-harvest and processing stages) whereas food waste is observed at the end of the chain (distribution and end consumer stages). Thus, food losses occuring at the end of the food chain (retail and final consumption) are rather called "food waste", which relates to retailers' and consumers' behaviour (Parfitt et al., 2010).

There are no so distinct boundaries for "food loss" and "food waste" definitions published by the World Resource Institute. In particular, "food loss" refers to food that spills, spoils, incurs an abnormal reduction in quality such as bruising or wilting, or otherwise gets lost before it reaches the consumer. Food loss is the unintended result of an agricultural process or technical limitation in storage, infrastructure, packaging, or marketing. "Food waste" refers to food that is of good quality and fit for human consumption but that does not get consumed because it is discarded-either before or after it spoils. Food waste is the result of negligence or a conscious decision to throw food away (Lipinski et al., 2013).

As our work analyses the retail sector, we use the term "food waste".

\section{Description of retail chains and stores studied}

In order to obtain a detailed information about the food waste flows generated in the retail sector, data from 21 retail stores, which belong to the 3 biggest retail chains in Lithuania (Retail chain I, Retail chain II, Retail chain III), were collected and analysed. Initially, 6 retail chains were contacted, but only the mentioned 3 agreed to participate in the study. All the chosen case stores belong to small (stores with $200-500 \mathrm{~m}^{2}$ sales area) or average size (stores $500-1,500 \mathrm{~m}^{2}$ sales area) food shopping centers with an average sales area $959 \mathrm{~m}^{2}$ (Table 1); the turnover of each store is up to EUR 116,000 per month. A different number of stores from each retail chain agreed to participate in the research: 13 stores in retail chain I, 4 stores in retail chain II, and 4 stores in retail chain III. Tables 1 and 2 provide information (an overview) about 3 retail chains and interviewed stores.

\section{Table 1}

Data for the retail chains and stores studied here, including the store sales area

\begin{tabular}{|c|c|c|}
\hline Retail chain & Store & Sales area $\left(\mathrm{m}^{2}\right)$ \\
\hline 1 & 2 & 3 \\
\hline \multirow{13}{*}{ I } & 1 & 1,300 \\
\hline & 2 & 1,200 \\
\hline & 3 & 1,000 \\
\hline & 4 & 1,100 \\
\hline & 5 & 900 \\
\hline & 6 & 293 \\
\hline & 7 & 1,800 \\
\hline & 8 & 1,000 \\
\hline & 9 & 1,900 \\
\hline & 10 & 500 \\
\hline & 11 & 978 \\
\hline & 12 & 277 \\
\hline & 13 & 1,222 \\
\hline \multirow{4}{*}{$\|$} & 1 & 272 \\
\hline & 2 & 920 \\
\hline & 3 & 500 \\
\hline & 4 & 272 \\
\hline \multirow{6}{*}{ III } & 1 & 1,200 \\
\hline & 2 & 1,600 \\
\hline & 3 & 1,400 \\
\hline & 4 & 500 \\
\hline & & Average: $959 \mathrm{~m}^{2}$ \\
\hline & & $20,134 \mathrm{~m}^{2}$ (overall) \\
\hline
\end{tabular}


Two of the retail chains are members of the Association of Lithuanian Trade Enterprises (ALTE), which unites almost 40 Lithuanian and foreign capital retail and wholesale trade companies, registered in the country. None of the studied chains was involved in the Retail Forum for Sustainability (EU organization, initiated by the European Comission), none of them was a member of the European Retail Round table.

\section{Table 2}

Market shares of the Lithuanian retail sector in 2012, according to the Lithuanian Free Market Institute

\begin{tabular}{c|c|c}
\hline Retail chains & Market share & Sales area, $\mathrm{m}^{2}$ \\
\hline 1 & 2 & 3 \\
\hline$I$ & $37 \%$ & 392,889 \\
\hline$I I$ & $16 \%$ & 628,622 \\
\hline IV * $^{*}$ & $11 \%$ & 172,871 \\
\hline Others * & $8 \%$ & 141,440 \\
\hline
\end{tabular}

${ }^{*}$ Did not participate in the study

\section{Data collection}

Semi-structured questionnaire survey was chosen as the data collection method as it allowed for collection of comprehensive and comparable information on food waste and causes in a relatively short time. Data collection at case stores took place from January to May in 2013; thus, the collected data is for the year 2012. The content of the questionnaire was formulated on the basis of Nordic research experience (Stenmarck et al., 2011). The survey was made up of 2 parts: one part was for the food waste quantity and management identification, and the other part was for highliting possible ways of prevention.

The first contacts with representatives for public relations of the retail chains were not successful as representatives politely refused to answer the questionnaire claiming that the information was highly confidential. When approaching directly store managers, they agreed to answer the questions, and the questionnaire was submitted by e-mail. The most comprehensive information was delivered by retail chains I and III.

\section{Data analysis procedure}

Five types of food (fish, meat, dairy, fruits and vegetables, bakery) were analysed in the study. First, absolute food waste amounts and waste composition generated in different retail chains and stores were evaluated. Then, the amounts were calculated to relative measure $\mathrm{kg}$ waste to $\mathrm{m}^{2}$ sales area and compared among the retail chains. Seasonal variations of food waste types and waste amount generated in 3 retail chains were analysed by calculating a monthly seasonal index. The seasonal index is a measure of how a particular season compares with the average season. The monthly seasonal index is defined by formula (Bacescu-Carbunaru Angelica \& Condruz-Bacescu Monica, 2013):

$\frac{\text { Waste amount of month,kg }}{\text { Waste average of } 12 \text { month,kg }}=$ Monthly seasonal index;

Using retail stores sales area and market share data, the results (in $\mathrm{kg}$ waste per capita) measured in the analyzed chain stores were aggregated to the Lithuanian national level and compared with neighbouring North European countries. Further, the results from interviews about the causes for retail food waste generation were discussed; attitudes and prevention possibilities were highlighted. For the comparative study, available literature on food waste assessment and prevention practices of Nordic countries was analyzed.

\section{Results and disscusions}

\section{Amounts and composition of food waste. A comparison with neighbouring countries in Northern Europe}

The total food waste amount generated by 21 analyzed stores was 149 tonnes per year. The amount distributes among the analyzed chains as follows: 103 tonnes per year in Retail chain I (13 stores, total sales area $\left.-13,469 m^{2}\right)$; 20 tonnes per year in Retail chain II ( 4 stores, total sales area - 1,964 m²); 26 tonnes per year in Retail chain III (4 stores, total sales area $-4,700 \mathrm{~m}^{2}$ ). The amount of food waste generated in each of the studied stores varied from 3 to 12 tonnes per year in Retail chain I, and from 3 to 6 tonnes per year in Retail chains II and III. 
Figure 1 illustrates an absolute food waste amount per product group from 21 retail stores. Fresh fruits and vegetables comprised the largest subgroup of retail food waste -40 tonnes (27\%). The other product subgroups presented in the waste flows were meat (32 tonnes, 22\%), milk and dairy (30 tonnes, 20\%), and fish (26 tonnes, 18\%).

\section{Fig. 1}

Absolute food waste per product group per year from 21 retail stores in Lithuania

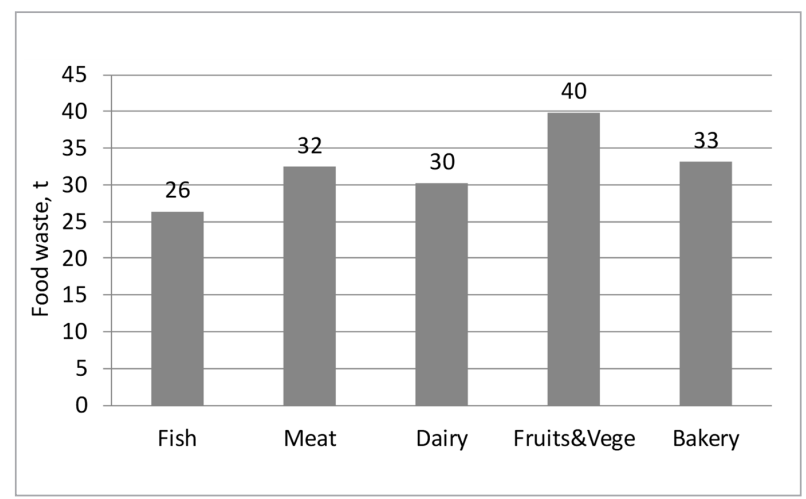

When expressed in relative units calculated as an average for all 3 retail chains, $1 \mathrm{~m}^{2}$ of sales area was contributing to the generation of the following amounts of the food waste: $1.98 \mathrm{~kg}$ of fruits and vegetables, $1.65 \mathrm{~kg}$ of bakery, $1.61 \mathrm{~kg}$ of meat, $1.5 \mathrm{~kg}$ of dairy, and $1.31 \mathrm{~kg}$ of fish waste (Figure 2). If we analyse different retail chains separately, fruit and vegetable waste dominated in retail chains I and III, but several types of food were wasted to the similar extent in retail chain II: fish and meat, as well as fruits and vegetables.

According to previous studies (Stenmarck et al., 2011) silimar types of products in waste dominate in all the Nordic countries and other regions. The difference is that fresh bread and grain product waste are on the top in Nordic countries followed by fruits and vegetables. Other important product groups are dairy products and meat. In the bottom of the list, there is canned, dried and frozen food, all with very long shelf lives. For example, a study in Finland (Stenmarck et al., 2011) reported the following wasted food products: bread and grain product $-35 \%$; fruits and vegetables $34 \%$; meat and fish $-12 \%$; and dairy products $-12 \%$. According to studies on request by the World Resource Institute, cereals comprise the largest share of global food loss and waste by the caloric content (53\%), while fruits and vegetables are the largest source of loss and waste on a weight basis. Fresh fruit and vegetables comprise the largest subgroup of retail food waste, but it is also estimated to be the subgroup with the highest uncertainty in recorded data (Lipinski et al., 2013). Our research results come together with the analysis of the World Research Institute results.

Table 3 provides a short overview compiled from different available literature sources on the estimated amounts of food waste in the retail sector of Lithuania

\section{Fig. 2}

Type of food waste per $\mathrm{m}^{2}$ of sales area in particular retail chains and total in all retail chains

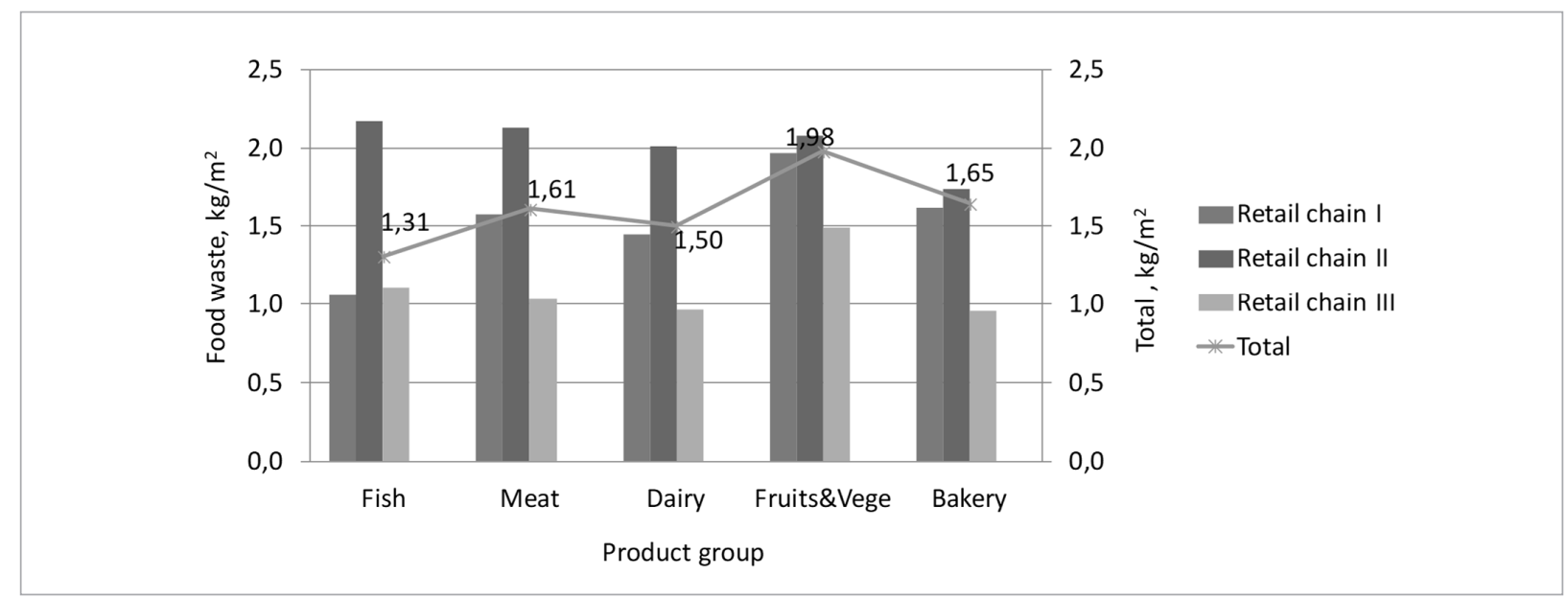


Table 3

Available data on retail food waste in the neighbouring countries in north Europe and a comparison with Lithuania

\begin{tabular}{|c|c|c|c|c|}
\hline Country & $\begin{array}{c}\text { Waste amount, } \\
\text { t/year }\end{array}$ & $\begin{array}{l}\text { Waste amount, } \\
\mathrm{kg} / \text { capita/year }\end{array}$ & & Comments \\
\hline 1 & 2 & 3 & & 4 \\
\hline \multirow[t]{3}{*}{ Denmarck } & 167,100 & 29.8 & \multicolumn{2}{|c|}{$\begin{array}{l}\text { Retail: (Stenmarck et al., 2016)directly linked with environmental (e.g. energy, } \\
\text { climate change, water, availability of resources referring to Environmental } \\
\text { Protection Agency Denmark, 2014, Undgå affald, stop spild nr. 5, Kortlægning af } \\
\text { madaffald I servicesektoren }\end{array}$} \\
\hline & $40,000-46,000$ & 8 & \multicolumn{2}{|c|}{$\begin{array}{l}\text { Retail: (Stenmarck et al., 2011) referring to Miljøstyrelsen, 2002, Håndtering af } \\
\text { organisk affald i dagligvarehandlen }\end{array}$} \\
\hline & 45,676 & & \multicolumn{2}{|c|}{$\begin{array}{l}\text { Retail, } 2001 \text { data: (BIO Intelligence Service, 2010) referring to Danish Environment } \\
\text { Ministry Food Waste Report, } 2010 .\end{array}$} \\
\hline Estonia & 6,270 & & \multicolumn{2}{|c|}{$\begin{array}{l}\text { (Stenmarck et al., 2016)directly linked with environmental (e.g. energy, climate } \\
\text { change, water, availability of resources referring to Moora H., Urbel-Piirsalu E., } \\
\text { Viilvere T., 2015, Toidujäätmete teke Eesti } \\
\text { kaubandus- ja toiduainetööstusettevõtetes, Stockholm Environment Institute }\end{array}$} \\
\hline Finland & $65,000-75,000$ & $12-14$ & \multicolumn{2}{|c|}{$\begin{array}{l}\text { Retail and wholesale: (Stenmarck et al., 2016)directly linked with environmental } \\
\text { (e.g. energy, climate change, water, availability of resources and (Katajajuuri et al., } \\
\text { 2014)and demonstrated that around } 130 \text { million kg of food waste are generated } \\
\text { each year ( } 23 \mathrm{~kg} \text { per capita/year }\end{array}$} \\
\hline Norway & 43,000 & & \multicolumn{2}{|c|}{$\begin{array}{l}\text { Retail: (Stenmarck et al., 2011) referring to Hanssen \& Olsen, 2008, Survey of Food } \\
\text { Loss in Norway. Pilot study for NorgesGruppen, Ostfold Research OR.20.08. }\end{array}$} \\
\hline Sweden & 69,676 & 7.3 & \multicolumn{2}{|c|}{$\begin{array}{l}\text { (Stenmarck et al., 2016)directly linked with environmental (e.g. energy, climate } \\
\text { change, water, availability of resourcesreferring to Swedish EPA, 2014, Food } \\
\text { Waste quantities in Sweden } 2012 \text {. }\end{array}$} \\
\hline & 83,500 & & \multicolumn{2}{|c|}{$\begin{array}{l}\text { Retail: (Stenmarck et al., 2011) calculated based on waste factors referring to } \\
\text { Background data to Avfall i Sverige, } 2008 .\end{array}$} \\
\hline & 39,000 & & \multicolumn{2}{|c|}{ (Stenmarck et al., 2011) } \\
\hline & 110,253 & 12 & \multicolumn{2}{|c|}{$\begin{array}{l}\text { (BIO Intelligence Service, 2010) referring to Naturvardsverket, 2010, Personal } \\
\text { Communication on Waste Generation, Stockholm, Sweden }\end{array}$} \\
\hline \multirow[t]{2}{*}{ Lithuania } & 14,768 & 5 & \multicolumn{2}{|c|}{$\begin{array}{l}\text { Based on this study: calculated from the number of shops and aggregated to the } \\
\text { country level }\end{array}$} \\
\hline & 30,246 & 8.89 & \multicolumn{2}{|c|}{ (BIO Intelligence Service, 2010) based on assumptions } \\
\hline \multirow[t]{2}{*}{ EU-28 } & & $9 \pm 2$ & Wholesale and retail & \multirow{2}{*}{$\begin{array}{l}\text { (Stenmarck et al., 2016)directly linked with } \\
\text { environmental (e.g. energy, climate change, water, } \\
\text { availability of resources estimates for } 2012\end{array}$} \\
\hline & & 7 & Retail & \\
\hline
\end{tabular}

and other neighbouring countries in Northern Europe. The reported waste amounts vary in a wide range. The numbers presented in Table 3 were generated by different methods, with different objectives, and different definitions used, which of course had an impact on the estimated amounts. Some studies were aiming to find just the retail waste food amount, others reported the total retail and wholesale amount. Therefore, it is difficult to compare them and judgements should always be made very carefully, but they can still give some general overview, and a preliminary evaluation can be made. The average food waste amount in the retail and wholesale sector in EU-28 is $9 \mathrm{~kg}$ per capita per year, and it is $7 \mathrm{~kg}$ if looking at the retail sector alone (Stenmarck et al., 2016)directly linked with environmental (e.g. energy, climate change, water, 
availability of resources. The largest generation rate was recorded in Denmarck (up to $29.8 \mathrm{~kg}$ per capita). According to our study, the quantity of food waste generated in the Lithuanian retail sector can be evaluated up to 14,768 tonnes per year, or $5 \mathrm{~kg}$ per year per capita. It is by one-third less than EU average, and even two times or more less if compared with some estimates for Nordic countries. The result of our study matches with one of the estimations in Sweden (Stenmarck et al., 2011) and in Estonia by Moora and others (Stenmarck et al., 2016)directly linked with environmental (e.g. energy, climate change, water, availability of resources. If calculated from these studies (waste amount divided by the number of inhabitants), waste generation in Sweden could have been about $4.2 \mathrm{~kg}$ per capita, and in Estonia about $5 \mathrm{~kg}$ per capita.

The total food waste generation rate was estimated to be some $173 \mathrm{~kg}$ per capita per year in EU-28 in 2012, and $7 \mathrm{~kg}$, or $4 \%$, of this was retail waste (Stenmarck et al., 2016). If we assume that total waste generation in the food supply chain in Lithuania equals to the EU average, $5 \mathrm{~kg}$ per capita estimated in the current study mean that the retail sector is responsible for some 3\% of waste in the food supply chain in Lithuania. Similar percentages were found in a number of other studies: 3.8\% in Sweden (Eriksson et al., 2014) and 3.3\% in Norway (Møller et al., 2012).

\section{A comparison of food waste generation among retail chains}

Food waste in $\mathrm{kg} / \mathrm{m}^{2}$ of sales area was estimated to be different in the studied retail chains. The lagest waste generation rate was $10 \mathrm{~kg} / \mathrm{m}^{2}$, while it was $7.6 \mathrm{~kg} / \mathrm{m}^{2}$ and $5.5 \mathrm{~kg} / \mathrm{m}^{2}$ in the other retail chains. The waste generation rate veries because of different attitudes and agendas in particular retail chains.

Retail chains I and III cooperated with Food Bank and other charity organizations, and nearly $40 \%$ of potential food waste (usually last day expire date products) were donated to people who need support.

One of these retail chains has started cooperation with Food Bank already in 2009. In 2012, they sent about 1,500 tonnes of "soon turning unsaleable food" to Food Bank. It is important to mention that it is the
Fig. 3

Food waste generation rate $\mathrm{kg} / \mathrm{m} 2$ of sales area from all the studied retail chains

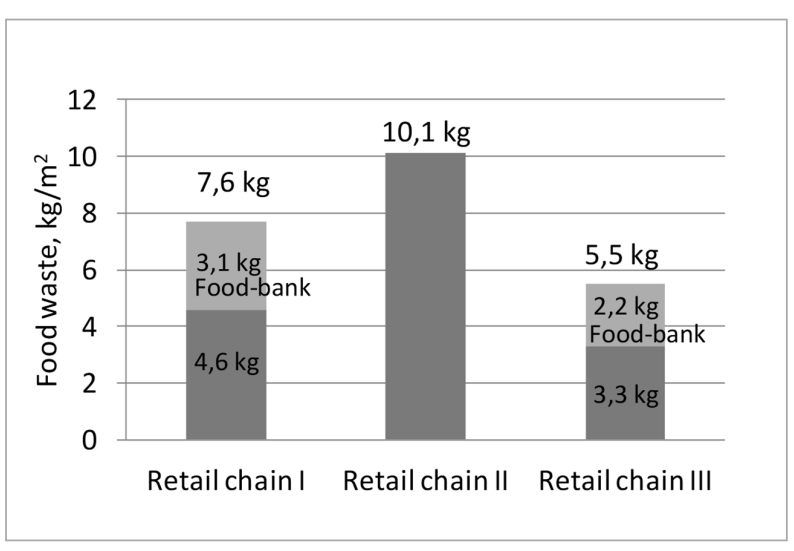

only retail chain in Lithuania where social responsibility principles were on their agenda; they are open to social projects, and open to share information. They are willing to reduce food waste and be friendlier to the environment. Part of the expired date food, which is not suitable for Food Bank, goes to farmer or animal food companies, and only the remaining part of food waste goes to waste containers.

Retail chain I has a registration system for food waste amounts in order to follow products, which are not, or less preferred, by customers. The system helps for better planning and odering products.

Chains II and III reported that they had a clear focus on their waste generation, simply as part of being a good retailer. Chain III replied that they had significantly reduced food waste amount by stricter control over planning and ordering, and by a proper consumer demand prognosis. They also started cooperation with Food Bank and use optimized selling: put products with short shelf lives on display, reduce prices on products close to the expiry date, once a week they sell fruits and vegetables with a big discount. Chain II also reported that they used procedures as proper planing, ordering, consumer demand prognosis, reduced prices on products close to the expiry date, in order to avoid food wastes, but they also reported that they had a priority of selling high quality food, full shelves and a big variety of products. They use this attitude 
because of market analysis results showing that consumers demand high quality, full shelves and a variety of food. Such values could be the reason why Retail chain II generated a relatively larger amount of waste in comparison with other studied retail chains.

\section{Analysis of seasonal variations}

The generated total waste amounts were quite stable over the year. The standard deviations for monthly seasonal index were the following: 0.047 for Chain I, 0.066 for Chain II, and 0.078 for Chain III (Fig. 4). Food waste recorded in July, August and September was about the average. October was the month with the bigest amount of total waste, especially in Retail chain III, being 20\% higher than average. June had the lowest total amount in 2 retail chains.

More pronounced variations could be observed when analysing different food categories separately.
According to monthly seasonal index calculations, the generated waste quantities in Retail chain I varied within similar narrow ranges for all food categories usually not getting out of $10 \%$ above or $10 \%$ below the average, depending on the category or the month. Only in October, fruit and vegetable waste exceeded the average by $22 \%$, and in December, fish waste was by $20 \%$ lower than the average. The lowest amounts of waste in all categories were recorded in January and August about $10 \%$ less than, or equal to, the average, and the lagest amounts were recorded in November and December, except for fish waste.

The largest monthly variations in Retail II were found for bakery and fish waste categories. For example, bakery waste amount in February was by $40 \%$ higher than the average, while in June it was by $35 \%$ lower than the average. June and September were the months with the lowest waste amount (except for

Fig. 4

The monthly seasonal index of waste per food category and total food waste generated in a particular retail chain

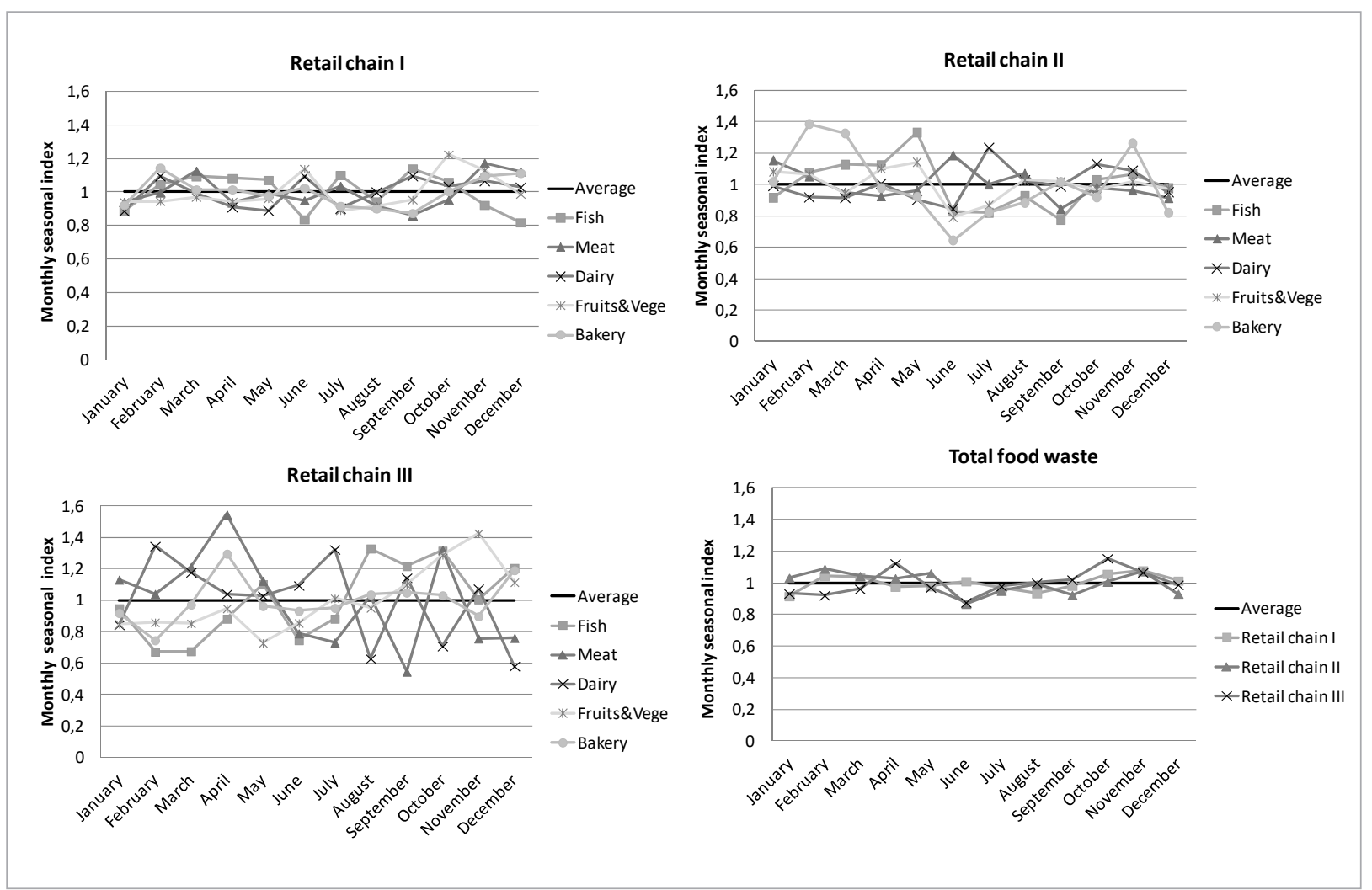


Fig. 5

The monthly and quarterly seasonal index of waste per product group generated in a particular retail chain
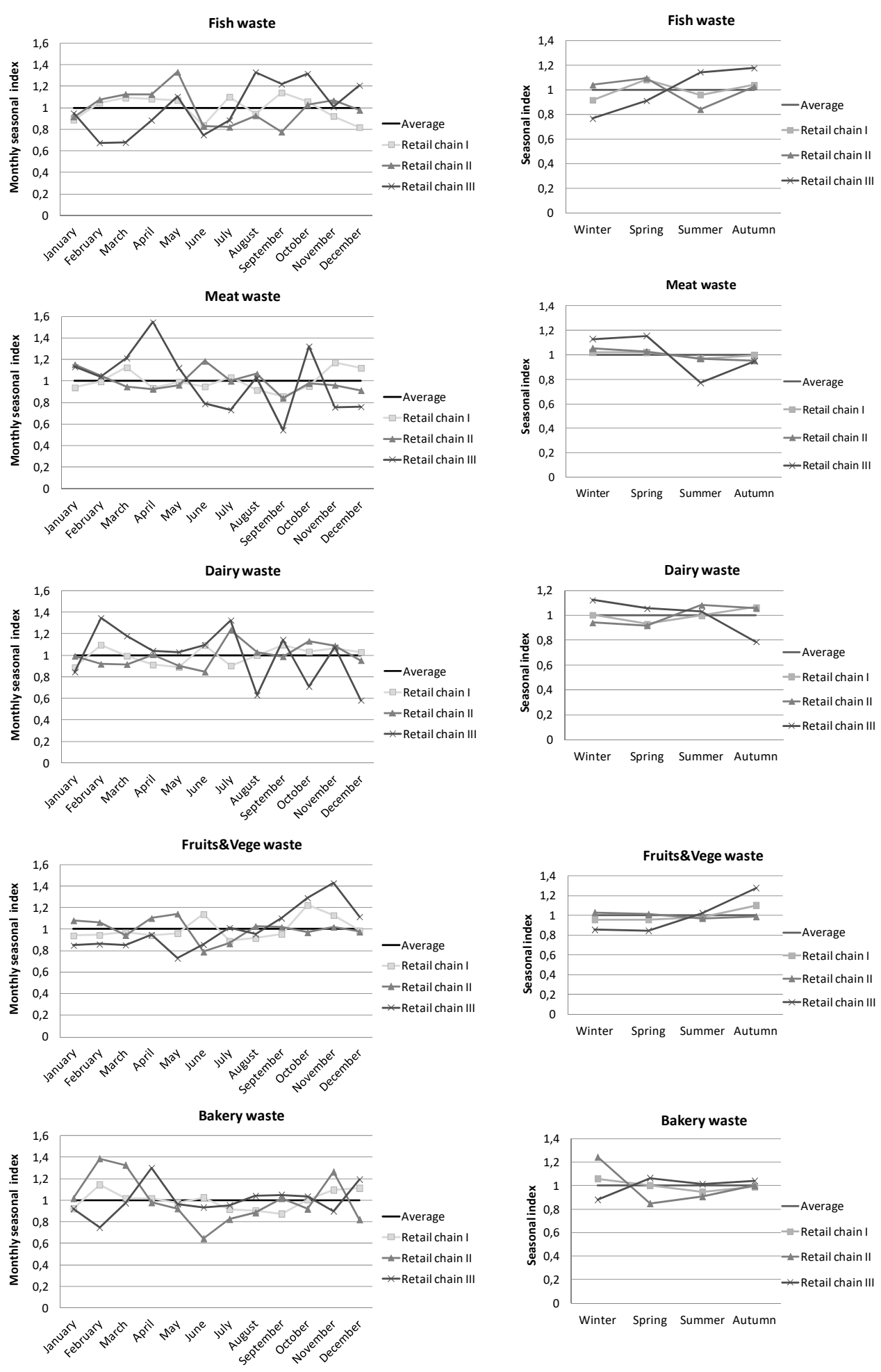
meat category), while November was with the highest waste amounts in most of the categories.

A high monthly variation was observed almost for all food waste categories in Retail chain III. The largest deviation from the average was recorded for meat waste, being 55\% more than the average in April, and $4 \%$ less than the average in September. For other food categories, waste amounts were fluctuating up and down during the year within the range of $4 \%$ above and $4 \%$ below the average. With some exeptions of food categories, the lowest food waste amounts were generated in January and June, and the highest in April and October.

A comparison of seasonal data reveals that more fruit and vegetable waste was generated in summer and especially in autumn seasons than in winter and spring seasons, and it could be due to the increased consumption during these months. On the contrary, in the meat category more waste was generated in winter and spring. No clear tendencies were observed for other food categories.

\section{Causes of retail food waste generation and possibilities of prevention}

The generation rate and composition of food waste depend on many factors, which must be taken into consideration when trying to explain waste generation. Retail chains reported the main reason for the food waste formation observed in retail stores to be expired shelf life (95\%), followed by exterior packaging damage (3\%) and quality problems (2\%). Food suppliers and quality controllers also contribute to food losses as they demand a higher quality of brands and a wider choice of goods.

However, expired shelf life of products is more a symptom of problems and it is interesting to focus why it is happening. According to interviews, the main reasons are as follows:

High quality requirements from consumers (according to consumer demands study, they expect full shelves, a variety of products and a very high quality fruits and vegetables). Much of the waste arises because consumers expect full shelves and reject food with a short shelf life period.

High quality requirements and strict rules intro- duced by authorities, among them Food and Veterinary Service.

Challenges related to proper handling, efficient planning and ordering of products.

According to a study of the Swedish Environmental Research Institute (Stenmarck 2011), all known causes for food waste generation in retail are more or less linked to customer's behaviour or to the shop-owners top priority goal to sell, which is a similar case in Lithuanian. The only difference could be revealed: the Nordic retail sector did not emphasize strict regulations by authorities for high quality requirements, as the Lithuanian retail sector did.

According to the study, the reasons for food waste generation in the Lithuanian retail sector could be the wrong attitude to the problem and a lack of willingness to share information, as well as a lack of cooperation in analysing and solving the problem. The Lithuanian retail sector is not open to discuss the problem yet. From 6 initially contacted retail chains, only 3 agreed to participate in the study, and only 1 of those 3 provided complete information. According to the IVL report (Stenmarck et al., 2011), a lack of willingnes to publish data to some extent also exists in Nordic countries. An exception is Norway, were detailed data are availabe through several projects, economically supported by the Ministry of Environment in Norway.

The study pointed out to the following issues of food waste prevention at the retail stage. It is important to find out what is true and what is not and take actions aiming to change the behavior and demands of consumers. Information campaigns and training for consumers and the sector itself about the amounts and the impact of food waste, actions at schools, festivals, restaurants with last day consumption products. More attention should be paid to the revision of the regulation containing unnecessary rules for supermarkets that increase the loss of products that are still good to use, change "best before dates", making easy to donate food.

The actual amounts of food waste need to be reported in the country on a regular basis. Engagement of different authorities, NGOs and chains for highlighting the issue, setting up the goals and working together under a common projects. 


\section{Conclusions}

A comparison of amounts and composition of food waste generated in different countries and regions is not straightforward because different methods, objectives, and definitions are used, which has an impact on the results. A preliminary assumption from the study is that the Lithuanian retail sector generates less food waste ( $5 \mathrm{~kg}$ per capita per year) compared with the EU average ( $7 \mathrm{~kg}$ per capita per year), and with the majority of Nordic countries. At the same time, the retail food waste generation rate in Lithuania is seems to be the same as in Estonia, which could be explained by similarities in the economic and social situation in both countries.

Fruits, vegetables and bakery products dominate in food waste both in Lithuania and in Nordic countries.

The main causes for food waste generation reported by the retail sector from both regions were similar more or less linked to customer's behaviour or to the shop-owners top priority goal to sell. The only difference was revealed: the Nordic retail sector did not

\section{References}

Bacescu-Carbunaru Angelica, \& Condruz-Bacescu Monica. (2013). Methods used in the seasonal variations analysis of time series. Romanian Statistical Review, (3), 18.

Beretta, C., Stoessel, F., Baier, U., \& Hellweg, S. (2013). Quantifying food losses and the potential for reduction in Switzerland. Supplementary Information. Waste Management, 33(3), 764773. https://doi.org/10.1016/j.wasman.2012.11.007

BIO Intelligence Service. (2010). Preparatory study on food waste across EU 27.

Edjabou, M. E., Petersen, C., Scheutz, C., \& Astrup, T. F. (2016). Food waste from Danish households: Generation and composition. Waste Management, 52, 256-268. https://doi. org/10.1016/j.wasman.2016.03.032

Eriksson, M., Strid, I., \& Hansson, P.-A. (2014). Waste of organic and conventional meat and dairy products-A case study from Swedish retail. Resources, Conservation and Recycling, 83, 4452. https://doi.org/10.1016/j.resconrec.2013.11.011

Eriksson, M., Strid, I., \& Hansson, P. A. (2012). Food losses in six Swedish retail stores: Wastage of fruit and vegetables in relation emphasize strict authorities regulation for high quality requirements as did the Lithuanian retail sector.

Most retail companies reported that they were willing to reduce food waste, because big amounts of food waste show they work inefficiently and have poor planning. One of the interviewed retail chains has social responsibility principles on its agenda.

The retail in Lithuania shows a lack of willingness to share information about food waste, and they are not open to discuss the problem. Of 6 initially contacted retail chains, only 3agreed to participate in the study. The main prevention strategy was food donation. More attention should be paid to actions changing the behavior of consumers, as well as to the revision of regulations.

Regarding the seasonal influence on waste generation, the most expressed tendency was an increase in fruit and vegetable waste in summer, and especially in autumn.

to quantities delivered. Resources, Conservation and Recycling, 68, 14-20. https://doi.org/10.1016/j.resconrec.2012.08.001

European Commision. (2011). Roadmap to a Resource Efficient Europe - \{SEC(2011) 1067 final $\}$ - SEC(2011) 1068 final $\}$ COM(2011) 571 final.

European Parliament Resolution (2011/2175(INI)). (2012). European Parliament resolution of 19 January 2012 on how to avoid food wastage: strategies for a more efficient food chain in the EU (2011/2175(INI)), (2175), 8.

FAO. (2009). Global agriculture towards 2050. High Level Expert Forum-How to Feed the World 2050, 1-4. https://doi.org/ http://www.fao.org/fileadmin/templates/wsfs/docs/Issues_ papers/HLEF2050_Global_Agriculture.pdf

Fox, T., \& Fimeche, C. (2013). Global Food Waste Not, Want Not. Institute of Mechanical Engineers. Retrieved from http://www. imeche.org/docs/default-source/reports/Global_Food_Report.pdf?sfvrsn=0

Gustavsson, J., Cederberg, C., \& Sonesson, U. (2011). Global food losses and food waste: Extent, causes and prevention. Or- 
ganization. https://doi.org/10.1098/rstb.2010.0126

Hanssen, O. J., Syversen, F., \& Stø, E. (2016). Edible food waste from Norwegian households - Detailed food waste composition analysis among households in two different regions in Norway. Resources, Conservation and Recycling, 109, 146-154. https:// doi.org/10.1016/j.resconrec.2016.03.010

Katajajuuri, J. M., Silvennoinen, K., Hartikainen, H., Heikkilä, L., \& Reinikainen, A. (2014). Food waste in the Finnish food chain. Journal of Cleaner Production, 73, 322-329. https://doi. org/10.1016/j.jclepro.2013.12.057

Koivupuro, H. K., Hartikainen, H., Silvennoinen, K., Katajajuuri, J. M., Heikintalo, N., Reinikainen, A., \& Jalkanen, L. (2012). Influence of socio-demographical, behavioural and attitudinal factors on the amount of avoidable food waste generated in Finnish households. International Journal of Consumer Studies, 36(2), 183-191. https://doi.org/10.1111/j.1470-6431.2011.01080.x

Lebersorger, S., \& Schneider, F. (2014). Food loss rates at the food retail, influencing factors and reasons as a basis for waste prevention measures. Waste Management, 34(11), 1911-1919. https://doi.org/10.1016/j.wasman.2014.06.013

Lipinski, B., Hanson, C., Lomax, J., Kitinoja, L., Waite, R., \& Searchinger, T. (2013). Reducing Food Loss and Waste. World Resource Institute, (June), 1-40. https://doi. org/10.2499/9780896295827_03

Møller, H., Vold, M., Schakenda, V., \& Hanssen, O. J. (2012). Mapping method for food loss in the food processing industry. Retrieved from https://www.ostfoldforskning.no/me$\mathrm{dia} / 1161 / 2712 . p d f$

Nahman, A., de Lange, W., Oelofse, S., \& Godfrey, L. (2012). The costs of household food waste in South Africa. Waste Management, 32(11), 2147-2153. https://doi.org/10.1016/j.wasman.2012.04.012

Parfitt, J., Barthel, M., \& Macnaughton, S. (2010). Food waste within food supply chains: quantification and potential for change to 2050. Philosophical Transactions of the Royal Society B: Biological Sciences, 365(1554), 3065-3081. https://doi. org/10.1098/rstb.2010.0126

Quested, T. E., Marsh, E., Stunell, D., \& Parry, A. D. (2013). Spaghetti soup: The complex world of food waste behaviours. Re- sources, Conservation and Recycling, 79, 43-51. https://doi. org/10.1016/j.resconrec.2013.04.011

Quested, T., \& Parry, A. (2011). New estimates for household food and drink waste in the UK. WRAP, (November), 1-19.

Schneider, F. (2013). Review of food waste prevention on an international level. Proceedings of Institution of Civil Engineers: Waste and Resource Management, 166(4), 187-203. https://doi. org/10.1680/warm.13.00016

Stenmarck, Å., Jensen, C., Quested, T., Moates, G., Buksti, M., Cseh, B., ... Östergren, K. (2016). Estimates of European food waste levels. Reducing food waste through social innovation. FUSIONS. Retrieved from https://www.eu-fusions.org/phocadownload/Publications/Estimates of European food waste levels.pdf\%5Cnhttps://phys.org/news/2016-12-quarter-million-tonnes-food-logistics.html\#nRlv

Stenmarck, Å., Jörgen Hanssen, O., Silvennoinen, K., \& Katajajuuri, J.-M. (2011). Initiatives on prevention of food waste in the retail and wholesale trades. (N. C. of M. S. Nordic Council of Ministers, Ed.). Nordic Council of Ministers. https://doi. org/10.6027/TN2011-548

Terry, L., Mena, C., Williams, A., Jenney, N., \& Whitehead, P. (2011). Fruit and vegetable resource maps. Wrap, (November 2009), 1-94.

Venkat, K. (2011). The Climate Change and Economic Impacts of Food Waste in the United States. International Journal on Food System Dynamics, 2(4), 431-446. https://doi.org/10.18461/ ijfsd.v2i4.\%x

Ventour, L. (2008). The food we waste. Food Waste Report V2 (Vol. 2). Retrieved from http://library.wur.nl/WebQuery/ $\mathrm{clc} / 1944512$

Walter, L. F., \& Marina, K. (2015). Food Waste and Sustainable Food Waste Management in the Baltic Sea Region (1st ed.). Springer International Publishing. https://doi.org/10.1007/9783-319-10906-0

Wikström, F., Williams, H., Verghese, K., \& Clune, S. (2014). The influence of packaging attributes on consumer behaviour in food-packaging life cycle assessment studies - A neglected topic. Journal of Cleaner Production, 73, 100-108. https://doi. org/10.1016/j.jclepro.2013.10.042 


\section{Lietuvos mažmeninès prekybos sektoriuje susidarančių maisto atliekų jivertinimas ir prevencijos priemonès: lyginamasis tyrimas}

\section{Diana Kliaugaitè, Jolita Kruopienè}

Aplinkos inžinerijos institutas, Kauno technologijos universitetas, Gedimino g. 50, Kaunas 44239, Lietuva

Maisto tiekimo grandinèje susidarančios maisto atliekos sukelia ne tik aplinkos taršos problemas, tačiau neša ir ekonominius nuostolius tiek gamintojams, tiek vartotojams, reikalauja papildomy ištekliu atlieku sutvarkymui bei yra prarasta galimybè pamaitinti alkstančius. Skaičiavimai rodo, kad maždaug 30\% viso pasaulio maisto produktu, pagamintu žmonėms, prarandami arba išvaistomi skirtinguose maisto tiekimo grandinès etapuose. Atskirai mažmeniness prekybos sektoriuje, išsivysčiusiose šalyse, susidaro apie $5 \%$ maisto atliekų. Maisto atliekų tyrimai atliekami tiek tarptautiniu, tiek nacionaliniu lygmeniu. Šie tyrimai dažniausia apima visoje tiekimo grandineje susidariusius maisto atlieku kiekius, tačiau rečiau nagrinèja atlieku kiekius ir ju susidarymo priežastis atskiruose tiekimo grandinės etapuose. Mažmeninės prekybos sektorius yra vienas iš maisto tiekimo grandinės dalyvių, kur duomenu apie maisto alieku susidarymo kiekius ir priežastis trūksta, ypač Vidurio ir Rytų Europos regione. Mažmeninès prekybos sektorius yra pakankamai uždaras ir dèl riboto informacijos atskleidimo, duomenu apie prekybos vietoje susidarančiu atliekų kiekius, rūšis, priežastis ir tvarkymo būdus nepakanka. Siekiant geriau jivertinti ir suprasti maisto atlieku problematiką ir nustatyti veiksmingas atlieku prevencijos priemones, būtina tiksliau jvertinti mažmeniniuose prekybos centruose susidariusių atlieku kiekius ir priežastis.

Šio darbo tikslas - jvertinti maisto atliekų kiekius Lietuvos mažmeninès prekybos sektoriuje, nustatyti atlieku susidarymo priežastis, bei palyginti su Vidurio ir Rytu Europos bei Skandinavijos regionuose esančia situacija, pasiūlyti atlieku prevencijos priemones. Duomenų rinkimui pasirinkta pusiau struktūrizuota apklausa, kurie leidžia surinkti išsamią bei palyginamą informaciją apie maisto atliekas per palyginti trumpą laiką. Duomenys buvo renkami 21 -oje mažmeninès prekybos parduotuvėse, kurios priklause 3-ims didžiausiems prekybos tinklams Lietuvoje. Palyginimui su kitomis šalimis buvo analizuojama literatūra ir moksliniai tyrimai susiję su maisto atliekų kiekių vertinimo ir prevencijos praktika Skandinavijos ir Vidurio Rytu Europos šalyse.

Šiuo tyrimu buvo nustatytas Lietuvos mažmeninės prekybos sektoriuje susidarančiu maisto atlieku kiekis, maisto atlieku sudetis, bei atskleistas prekybos sektoriaus požiūris i maisto atlieku problemas bei noras jas spresti. Taip pat buvo ivertinti maisto atlieku kiekio svyravimai priklausomai nuo metu sezono. Lyginant Vidurio ir Rytu Europos bei Skandinavijos regionus, buvo išskirtos skirtingos maisto atlieku susidarymo priežastys bei galimos maisto atleikų prevencijos priemonès.

Raktiniai žodžiai: maisto atliekos, prekybos centrai, atliekų prevencija, sezoniškumas. 